\title{
切欠引張強さ比の応力三軸度およびひずみ硬化指数依存性*
}

\author{
大 橋

\section{Dependence of Notch Strength Ratio on Stress Triaxiality and Strain Hardening Exponent for Structural Steels}

真*1

\author{
Makoto OHASHI*2 \\ *2 National Research Institute of Police Science, \\ 6-3-1 Kashiwanoha, Kashiwa, Chiba, 277-0882 Japan
}

\begin{abstract}
Dependence of notch strength ratio on stress triaxiality and strain hardening exponent was investigated for a variety of structural steels. Both the notched specimens with different notch root radii and the unnotched specimens were employed to obtain a wide range of stress triaxiality. All specimens were loaded up to break under tensile loading at room temperature. Notch strength ratio was defined by a ratio of notch tensile strength to tensile strength of the material. The notch tensile strength required to break the notched specimen depends on the stress-state characterized by stress triaxiality. Notch strength ratio increased with increasing stress triaxiality, which eventually reached the limiting value in the range of high stress triaxiality. The limiting notch strength ratio showed a clear dependence on the strain hardening exponent, and could be used conveniently to estimate the upper limit load to break the mechanical component in failure analysis.
\end{abstract}

Key Words : Notch Strength Ratio, Stress Triaxiality, Strain Hardening Exponent, Limiting Notch Strength Ratio, Failure Analysis

\section{1. 緒}

\section{言}

機械・構造物の破壊事故の原因究明に際しては，破 断面の検査，金属組織的な検査など，多くの観点から 検查䘮行い，事故原因を明確に特定する ${ }^{(1)}$. しかし， 事故原因をより厳密に特定するには，破断時に加わっ た負荷荷重の推定が必要となる。この場合，有限要素 法, 破壊力学に基づいた解析, 再現的な強度試験など, 詳細な力学的検討が必要となる.

一方，詳細な解析とは別に，構造部材に加わった負 荷荷重の推定に関しては，疲れ限度比など，主要な機 械的特性値に対する破壊特性値の比率が重要な強度指 標値として活用しうる．例えば，回転曲げにより疲労 破断した場合，疲れ限度と引張強さの比率で示される 疲れ限度比法，一般的な鋼材では $0.5^{(2)}$ ，鋳鋼では 0.3 程度となる ${ }^{(3)}$. ねじりと回転曲げの疲れ限度の比率は, 一般的な鋼材では $0.5 \sim 0.7$ 程度となる ${ }^{(4)}$. また，転が り疲れ限度は，広範な金属材料について引張強さなど の関数として示されている ${ }^{(5)}$. 破壊力学による強度評 価に関しても，下限界応力搪大係数範囲は硬さと相関 を示すことが指摘されている ${ }^{(6)}$. したがって，回転曲

* 原稿受付 2008 年 5 月 21 日.

*1 正員, 科学警察研究所 (昰 277-0882 柏市柏の葉 6-3-1).

E-mail : ohashi@nrips.go.jp
げなどにより疲労破断した場合，部材に加わった繰返 し応力の下限値は引張強さなどから簡便に推定が可能 となる.

このような観点から，本報では，構造部材の破断時 に加わった引張荷重の推定に関して, 応力三軸度の変 化に伴う上限值を，機械的特性值に基づいた簡便な指 標值を用いて推定するため以下の検討を行った．すな わち，破壊事故の一般的なプロセスは，設計ミス・施 エミスなどに起因して部材の一部から疲労き裂が発生 ・成長し，残された部材断面が荷重に耐え切れず，延 性的に破断して大規模な事故に至る例が多い，したが って，欠陥を有する構造部材の破断に要した荷重は， 残された部材断面を延性破断させるのに要した最大荷 重となる.このため, 構造部材の破断時に加わった引 張荷重の推定に際しては，延性き裂の発生を対象とし た破壊勒性値の評価とは異なり，欠陥を有する部材の 延性破断に要した最大荷重の評価が必要となる.

この点に関しては, 従来, 切欠試験片の破断に要し た最大応力を示寸切欠引張強さと, 引張強さの比率で 示される切欠引張強さ比の変化特性について検討がな されている(7)(8). その結果, 切欠引張強さ比は, 応力 の多軸性とともに変形特性によっても影響を受けるこ とが示されている. しかし，応力多軸性の影響に関し ては，破壊勒性值の板厚依存性に対する検討と同様， 
応力三軸度の増加に伴う切欠引張強さ比の飽和特性を 明らかにすることが，破断時に加わった引張荷重の上 限値を推定する上では重要となる.

このため，本報では，それらの検討 ${ }^{(7)(8)} に$ に比して応 力三軸度の高い切欠試験片を用い，切欠引張強さ比の 飽和特性とともに，その上限值となる飽和切欠引張強 さ比を，強度レベルが異なり，変形特性の異なる 6 種 の構造用鋼材について検討した．また，変形特性值の 影響に関しては，局部伸びと全伸びの比率 (7)(8)に比し て, 切久試験片の力学的特性を規定するより重要な変 形特性値と考えられるひずみ硬化指数と切欠引張強さ 比との関係について検討を行った.

\section{2. 実 験 方 法}

$2 \cdot 1$ 供試材およひ試験片＼cjkstart供試材は，2 種の一 般構造用圧延鋼材 JIS SS400，2種の溶接構造用圧延 鋼材 JIS SM520B, SM570, 溶接構造用高降伏点鋼板 JIS SHY685, ニッケルクロム鋼鋼材 JIS SNC631 である. 2 種の SS400を SS400 (A)，(B) とする. 6 種の鋼材の 降伏応力 $\sigma_{y}$, 引張強さ $\sigma_{B}$, 伸び $\delta_{T}$, ひずみ硬化指 数 $n$ を表 1 に示す.

Table1 Mechanical properties of the materials

\begin{tabular}{lcccc} 
& $\sigma_{y}$ & $\sigma_{B}$ & $\delta_{T}$ & $n$ \\
& $(\mathrm{MPa})$ & $(\mathrm{MPa})$ & $(\%)$ & \\
\hline SS400(A) & 308 & 463 & 32.5 & 0.256 \\
SS400(B) & 328 & 474 & 31.0 & 0.200 \\
SM520B & 396 & 579 & 23.6 & 0.213 \\
SM570 & 522 & 635 & 19.9 & 0.152 \\
SHY685 & 730 & 824 & 15.2 & 0.065 \\
SNC631 & 771 & 871 & 16.8 & 0.119 \\
\hline
\end{tabular}

実験には，応力三軸度を変化させる目的で, 直径 10 $\mathrm{mm} の$ 平滑丸棒試験片, 切欠先端半径 $\mathrm{R}$ を $6,3,1,0.5$, $0.25,0.1 \mathrm{~mm}$ 之 6 種に変化させた, 外径 $20 \mathrm{~mm}$, 内径 10 $\mathrm{mm}$ の円周切欠付き丸棒試験片を用いた. 試験片形状を 図 1 に示す。それらの試験片について，平滑丸棒試験 片の引張強さ, 切欠試験片の切欠引張強さを公称応力 一伸び線図上で求めた。

破断試験に加えて, SS400 (B) , SM520B, SM570 の R6, R1, R0. 5, R0.1mm 試験片については, 除荷試験により公称 忘力と切久断面上の平均ひずみ比率との関係を破断点 近傍まで求め, 切欠引張強さにおけるき裂の発生状況 とともに，切欠断面上の平均ひずみ比率を求めた．平

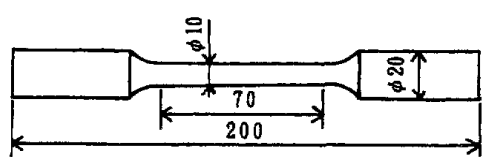

(a) Unnotched tensile specimen $\mathrm{R}=6,3,1,0.5,0.25,0.1$

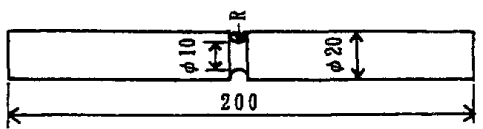

(b) Notched tensile specimen

Fig.1 Geometries of tensile specimens (dimensions in $\mathrm{mm}$ )

均ひずみ比率は，切欠断面上の平均ひずみと一様伸び の比率であり，本報では式(1)により算出した切久断面 上の平均真ひずみと，一様伸びに相当する真ひずみを 表すひずみ硬化指数の比率で示した.

$$
\begin{aligned}
\varepsilon_{m} & =2 \ln \left(d_{0} / d\right) \\
\varepsilon_{m} & : \text { 平均ひずみ } \\
d_{0} & : \text { :試験前の切欠断面直径 } \\
d & \text { :除荷後の切久断面直径 }
\end{aligned}
$$

$2 \cdot 2$ 応力三軸度 平滑丸棒試験片と 6 種の切欠 試験片について, 破断時の応力三軸度を Bridgman の近 似式(2)により求めた ${ }^{(9)(10)}$. 応力三軸度は変形過程にお いて変化するが, 本報では式(2)より算出した破断時の 応力三軸度を, 個々の試験片の応力三軸度の代表的な 值として, 切欠引張強さとの関係を検討した. 切欠底 部の曲率半径の測定例を $\mathrm{R} 0.5 \mathrm{~mm}$ 試験片について 図 2 に示す. 曲率忙破断後の切欠底部の形状に内接する円 の半径として, 4 力所の測定から平均值を求めた.

$$
\begin{aligned}
& \sigma_{m} / \sigma_{e}=1 / 3+\ln (1+d / 4 R) \\
& \sigma_{m} / \sigma_{e}: \text { 応力三軸度 } \\
& \sigma_{m}: \text { 静水応力 } \\
& \sigma_{e}: \text { 相当応力 } \\
& d: \text { : 破断後の最小断面直径 } \\
& R: \text { 破断後の切欠底部曲率半径 } \\
& \text { Fracture surface,- - } \\
& \text { Profile of notch root }
\end{aligned}
$$

Fig.2 Measurement of profile radius of notch root after fracture

\section{3. 実験結果および考察}

\section{$3 \cdot 1$ 切欠試験片の応カ一伸び線図 6 種の鋼材}

のうち，5種の鋼材，SS400(A)，SS400(B)，SM520B， SM570, SNC631 の6 種の切欠試験片は, ほぼ同様の破 


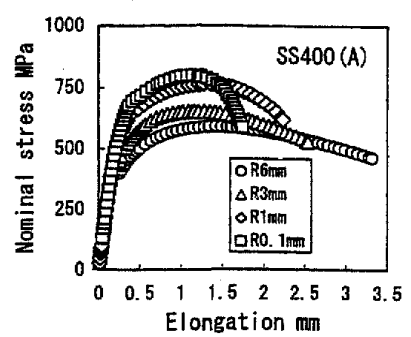

Fig.3 Nominal stress-elongation curves for SS400(A)

壊挙動を示している。このうち, 図3には, SS400(A) の R6，R3，R1，R0.1mm 試験片について代表的な公称応 カ一伸び線図を示す.上記の5種の鋼材の場合，切欠 の鋭いR0.1mm 試験片を含め,いずれの試験片も破断に 要した最大応力である切欠引張強さに到達後, 明瞭に 応力低下を伴って破断している. 一方, 延性のやや低 いSHY685のR1，R0.5，R0.25，R0.1mm 試験片では，全 断面降伏後の応力上昇過程において, 最大応力で応力 低下を伴うことなく破断している。このため，それら の 4 種の切欠試験片では破断時の最大応力を切欠引張 強さとした.

$3 \cdot 2$ 切欠引張強さおよび切欠引張強さ比の応力三 軸度依存性 6 種の鋼材の引張強さ，および切欠引 張強さを応力三軸度に対して図 4 に示す。 6 種の鋼材 のうち, SHY685 の R1mm 以下の 4種の切欠試験片では, 切欠引張強さで応力低下を伴うことなく破断している. このため, それらの試験片では, 応力低下を生じる領 域まで変形が可能であれば，切欠引張強さはやや高い 値を示すと考えられる. しふし，いずれの鋼材に関し

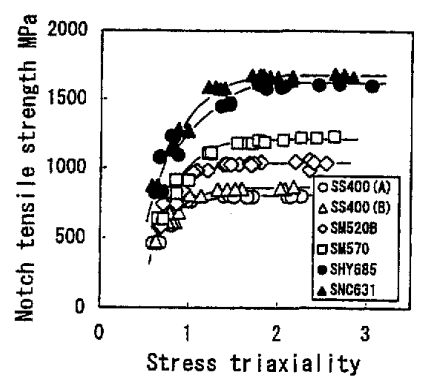

Fig.4 Relation between notch tensile strength and stress triaxiality

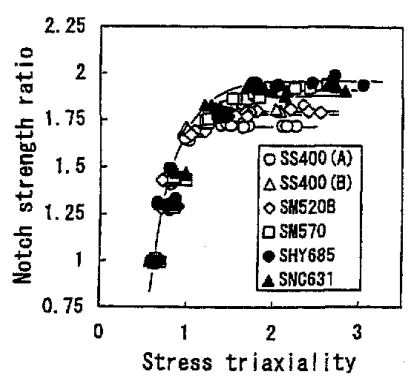

Fig.5 Relation between notch strength ratio and stress triaxiality
ても，切欠引張強さは，個々の試験片の塑性拘束の程 度を示守力三軸度の増加とともに上昇しており，応 三軸度の高い試験片では飽和する傾向を示している。 同様に, 切欠引張強さと引張強さの比率で示した切欠 引張強さ比を，応力三軸度に対して図 5 に示す。

いずれの鋼材の切久引張強さ比も, 応力三軸度の増 加とともに上昇した後，空力三軸度の高い領域では飽 和している. 切欠引張強さ比が飽和傾向を示している R0. 5, R0. 25, R0. $1 \mathrm{~mm}$ 試験片の切欠引張強さ比の平均 值を飽和切欠引張強さ比とする. 飽和切欠引張強さ比 は, SS400 (A)では 1.72, SS400(B)では 1.8, SM520B で は1.79, SM570では 1.89，SHY685では 1.96，SNC631 では 1.92 であり,個々の鋼材の変形特性に応じた差異 を示していると考えられる.

切久引張強さ, 切欠引張強さ比の飽和特性に関して は，切久試験片における延性き裂発生時のひずみは， R0. 5，R0. 2mm 試験片ではき裂試験片と比べて差がない とされている(10). したがって，R0.5〜0.2mm 程度以下 の切欠の鋭い試験片では，延性的な破壊挙動に及ぼす 応力三軸度の影響はほぼ飽和していると考えられる。

また，破断後の切欠断面直径から，式(1)を用いて求め た個々の試験片の破断ひずみは，いずれの鋼材につい ても延性の低下を促進する応力三軸度の増加とともに 低下寸る傾向を示している.このため, 式(2)より算出 した応力三軸度はおおむ称妥当な值を示していると考 えられる.

\section{$3 \cdot 3$ 切欠試験片の応力一平均ひずみ比率線図}

6 種の鋼材のうち, SNC631 を除いた 5 種の鋼材の R $0.1, \mathrm{R} 0.25, \mathrm{R} 0.5 \mathrm{~mm}$ 試験片など, 応力三軸度の高い試 験片では, ディンプル破面にへき開破面が一部混在し た破断面を示している.このため，延性き裂の発生に 伴う応力低下， へき開破壊への遷移が切欠引張強さの 飽和特性に影響を及ぼしていることも考えられる。 こ の点に関しては, SS400 (B), SM520B，SM570のR0.1, R0.5，R1，R6mm試験片について，切欠引張強さにおけ る延性き裂の発生状況を検討した。

4 種の試験片のうち，R0.1，R6mm 試験片について求 めた公称応力一切欠断面上の平均ひずみ比率線図を図 6 に示す. 個々の試験片の切欠引張強さを一で示す. 除荷試験により求めた延性き裂の発生点を $\Rightarrow て ゙$ 示す.

4 種の試験片のうち， R0.1mm 試験片では，切久引張 強さに到達後，応力がやや低下した時点において延性 き裂が発生している.この点については, 塑性拘束の 高い側溝付き裂試験片では，延性き裂は最大応力近傍 で発生することが示されており ${ }^{(11)}$ ，切欠の鋭い試験片 では同様の傾向を示していると考えられる. それに対 


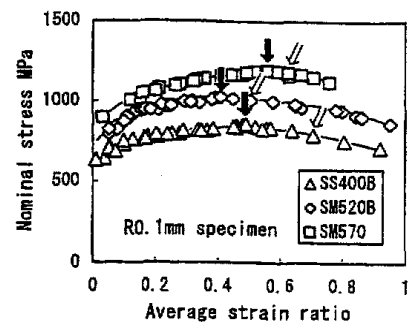

(a) $\mathrm{R} 0.1 \mathrm{~mm}$ specimen

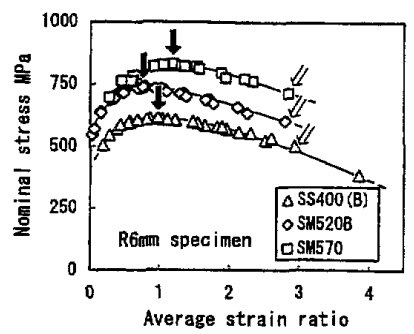

(b) R6mm specimen

Fig.6 Nominal stress - average strain ratio curves

し, R6mm 試験片では, 切欠引張強さに到達後, 応力が 明瞭に低下した状況下で延性き裂が発生している．R 0. 5, R $1 \mathrm{~mm}$ 試験片についても, 切欠引張強さに到達後, 态力が明睹に低下した後に延性き裂が発生している.

一方，延性き裂からへき開破壊への遷移は応力がさら に低下した破断時と考えられる。このため，延性き裂 の発生に伴う応力低下，へき開破壊への遷移は切欠引 張強さに影響を及ぼしていないと考えられる.

\section{4 切欠引張強さ比之限界平均ひずみ比率の関係}

延性き裂は切欠引張強さに到達後，応力低下の過程 で生じている.このため, 切欠引張強さは, 切欠試験 片が最大応力に到達して不安定変形を開始寸る, 平滑 丸棒試験片の引張強さに相当する応力と考えることが 出来る.

この場合，各種切欠試験片の切久引張強さにおける 切欠底部の限界ひずみは，ひずみ勾配の影響により， 平滑丸棒試験片の一様変形の限界ひずみである一様伸 びと比べて高い值を示している(12X13)．また，ひずみ勾 配が高くなるほど，塑性拘束の影響により限界ひずみ は上昇すると考えられる(14). したがって，切欠が鋭く， ひずみ勾配の高い試験片では(15)，切欠底部の限界ひず みがより高い值に到達するまで引張荷重が上昇し，切 欠引張強さが高い值を示すと考えられる．この点に関 しては，切欠試験片の大規模降伏状態における応力場 は，切欠鋭さと切久底部の最大ひずみにより一意的に 決定されており ${ }^{(16)}$ ，限界ひずみは切欠試験片の力学的 特性を規定する重要なパラメータと考えられる。

一方，切欠引張強さ比は，切久底部に㧈ける限界ひ
ずみが一様伸びに比してどの程度上昇しているか，切 欠底部の塑性拘束の強さを反映した両者の比率と相関 を示していると考えられる.このため，本報では，切 欠底部の限界ひずみの増加に対応して上昇していると 考えられる，切欠断面上の平均ひずみに対する一様伸 びの比率と，切欠引張強さ比との関係を検討した。 図 6にR0.1，R6mm 試験片についての線図を示した SS400 (B), SM520B，SM570の 4 種の切久試験片の公称応力平均ひずみ比率線図上で, 個々の試験片の切久引張強 さにおける平均ひずみ比率を限界平均ひずみ比率とし て求め, 切欠引張強さ比に対して図7に示す.

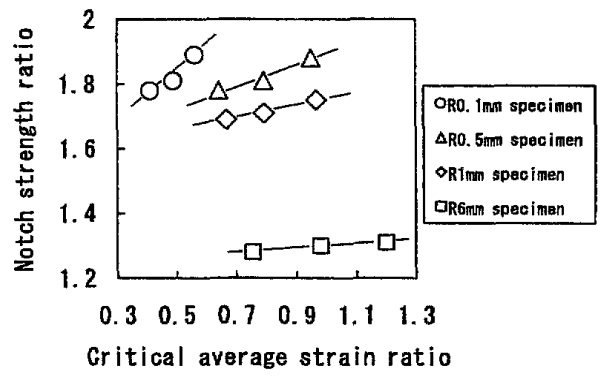

Fig.7 Relation between notch strength ratio and critical average strain ratio

切欠引張強さ比は，切欠の鋭い試験片では塑性拘束 の程度が上昇して高い值を示しており，切欠が鈍く， 切欠引張強さ比の低い $\mathrm{R} 6 \mathrm{~mm}$ 試験片ではその変化もわ ずかであるが，4種の試験片における限界平均ひずみ 比率は，図7に示したR0.1，R0.5，R1，R6mm のいずれ の試験片についても，SM520B，SS400(B)，SM570 の順 にひずみ硬化指数の低い鋼材ほど高い值を示しており， その比率の増加とともに切欠引張強さ比は上昇してい る. 寸なわち，切久試験片が最大応力を示す限界平均 ひずみ比率は，切久鋭さが同一の試験片においても， ひずみ硬化指数の低い鋼材ではやや高い值を示してい る.このため，その比率の高い試験片ほど，切久底部 の限界ひずみの増加に対応して，切欠断面上の平均ひ ずみが一様伸びに比してより高い値に達するまで引張 荷重が上昇し，切欠引張強さ比が高い值を示している と考えられる.

\section{$3 \cdot 5$ 飽和切欠引張強さ比とひずみ硬化指数の関係}

図 7 に示した結果加ら，切欠引張強さ比は，切欠鋭 さとともに，ひずみ硬化指数の影響を受けていると考 えられる.この点については，切欠試験片あるいはき 裂試験片の力学的特性は, 個々の材料の忘力ーひずみ 関係を規定するひずみ硬化指数の影響を受けていると 考えられ，例えば弾塑性状態における切欠底部の最大 ひずみは，負荷応力などとともにひずみ硬化指数の関 
数として近似的に与えられている(17). 切久底部の鈍化 挙動もひずみ硬化指数の影響を受け，ひずみ硬化指数 が低い材料では，より明瞭に鈍化が進行することが示 されている(18)(19). 切久底部のひずみ分布に相当すると 考えられる，ひずみ勾配を生じている引張試験片が， 最大応力に到達して不安定変形を開始する限界ひずみ も，ひずみ硬化指数の関数として与えられているる ${ }^{(14)}$.

また，き裂端近傍のひずみ場は，き裂端からの距離 を $r$ ，ひずみ硬化指数を $n$ とした場合，HRR 場では $r^{-I /(1+n)}$ で表される特異性を示している(20).このため, 本報では, 切欠引張強さ比に及ぼすひずみ硬化指数の 影響を検討するため, 切欠引張強さが飽和傾向を示し ている切欠の鋭い試験片では $r^{-1 /(1+n)}$ 特異性に基づ いたひずみ分布を示していると考光，切久底部のひず みの分布に相当する分布を以下のように便宜的に求め た. 6 種の鋼材について, 切欠底部近傍の任意の䇢所 $r_{0}$ における $r^{-1 /(1+n)}$ を 1 として, 切欠端部の各位置 における $r^{-1 /(1+n)}$ との比率分布を，それぞれの鋼材 のひずみ硬化指数から求めた. 6 種の鋼材について求 めた $r^{-1 /(1+n)}$ の比率分布を図 8 に示す. 横軸は $r_{0}$ に 対する比率 $r / r_{0}$ を示す。

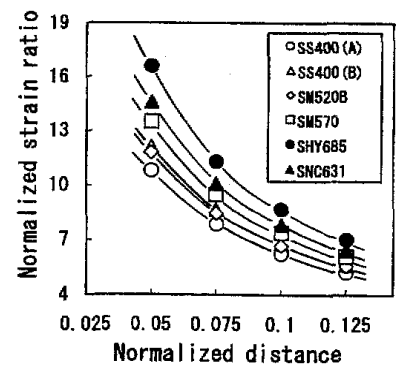

Fig.8 Normalized strain ratio distribution

SHY685のひずみ硬化指数はSS400 (A)の約 $1 / 4$ であり， 切久端部におけるひずみ比率は，ひずみ硬化指数の低 い鋼材ほど上昇して，分布の勾配は高くなる傾向を示 している. したがって，ひずみ硬化指数の低下は，切 欠の先鋭化 ${ }^{(15)}$ と同等の効果を示していると考えられ， ここでは横軸の比率が 0.05 の箇所におけるひずみ比 率を、ひずみ比率の分布の勾配を示す值として飽和切 欠引張強さ比に対して図9に示寸。

飽和切欠引張強さ比は, 切欠底部のひずみ比率の分 布の勾配が増加するとともに上昇する傾向を示してお り，ひずみ硬化指数が低く，ひずみ勾配の高い切欠試 験片の端部では，低ひずみ領域による塑性拘束が増大 して, 切欠引張強さ比が上昇していると考えられる. このため, 切欠引張強さ比は, 切欠鋭さの変化に加え て，ひずみ硬化指数の影響を受けていると考えられ，

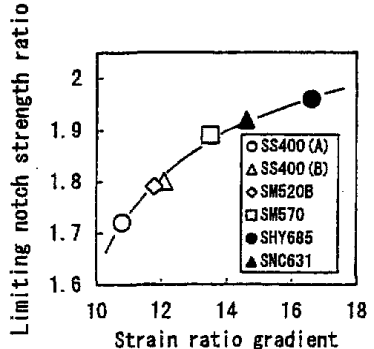

Fig.9 Relation between limiting notch strength ratio and strain ratio gradient

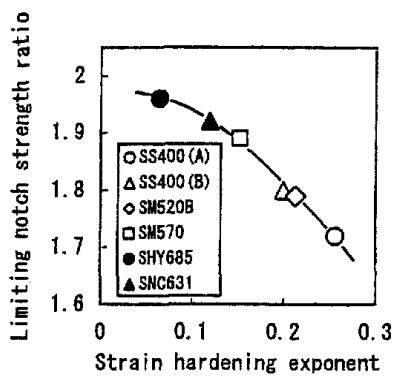

Fig.10 Relation between limiting notch strength ratio and strain hardening exponent

図 10 には, 飽和切久引張強さ比とひずみ硬化指数の関 倸を示す， 6 種の鋼材の飽和切欠引張強さ比は，ひず み硬化指数の低下とともに上昇する傾向を示しており， いずれの鋼材の飽和切欠引張強さ比も, 両者の関係を 近似した式(3)により,ひずみ硬化指数加ら容易に推定 が可能となる.このため，破壞事故の原因究明に際し ても, 飽和切欠引張強さ比は, 破断時に加わった引張 荷重の上限値を推定する上で重要な強度指標值として 活用しうると考えられる。

$$
\begin{gathered}
y=-3.32 n^{2}-0.23 n+1.99 \\
y: \text { 飽和切欠引張強さ比 } \\
n: \text { ひずみ硬化指数 }
\end{gathered}
$$

なお，図 11 には, 切欠引張強さ比との相関が指摘さ れている, 全伸びに占める局部伸びの比率(7)(8) とひずみ 硬化指数の関係を示す．局部伸び比率は，一様伸びに 相当するひずみ硬化指数の低下とともに上昇する傾向 を示しており, 飽和切欠引張強さ比とも相関を示して いる. しかし，局部伸びが全伸びに占める局部伸び比 率は物理的な意味が必ずしも明確ではなく，板厚の增 加に伴う全伸びの上昇によっても変化すると考えられ る ${ }^{(21)}$.このため, 安定した材料定数とはならないこと が考えられ，切欠引張強さ比は，切欠鋭さとともに， 変形特性値の影響ししては，ひずみ硬化指数の低下に 伴う変形の局所化により上昇する傾向を示していると 考えられる. 


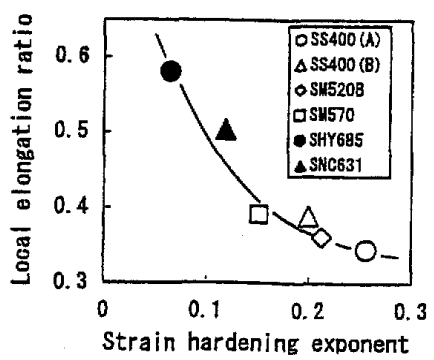

Fig.11 Variation of local elongation ratio with strain hardening exponent

機械・構造物の力学的な解析に際しては，延性的な 破壊挙動を対象とした大変形の解析を行う場合，ボイ ドの発生などに係わる材料特性值を適切に設定する必 要があり，それらの值を引張特性值から推定するため の検討もなされている(22)，破壊靭性值に関しても，引 張特性に基づいた簡便な評価が検討されている ${ }^{(23)}$. し たがって，詳細な解析とは別に，疲れ限度比などと同 様 ${ }^{(2)}$ (5)，引張特性に基づいた簡便な強度評価は実用的 には極めて重要と考えられ，ひずみ硬化指数から容易 に推定が可能な飽和切欠引張強さ比は，構造部材の破 断に要した引張荷重の上限値を推定する上で重要な強 度指標値として活用しうると考えられる。

\section{4. 結論}

強度レベルが異なり，変形特性の異なる 6 種の鋼材 について，応力三軸度の変化に伴う切欠引張強さ比の 飽和特性とともに，飽和切久引張強さ比とひずみ硬化 指数の相関について検討在行った. 結論を以下に示す. （1）6種のいずれの鋼材に関しても，切久引張強さ，切 久引張強さ比は，応力三軸度の増加とともに上昇して 飽和する傾向を示している.

（2）6種の鋼材の飽和切久引張強さ比は $1.72 \sim 1.96$ 程 度の值を示しており，ひずみ硬化指数の低下とともに 上昇する傾向を示している.

（3）飽和切久引張強さ比は，ひずみ硬化指数から容易に 推定が可能であり，構造部材の破断に要した引張荷重 の上限值を推定する上で簡便かつ重要な強度指標値と して活用しうると考えられる。

\section{文献}

(1) Ohashi, M., Forensic Science, Vol.2(in Japanese), (2005), pp.115-143,Reibunsya.

(2) Abe, T., Furuya, Y., Matsuoka,S., Trans. JSME, Series A,
Vol.67, No.664(2001), pp.1988-1995.

(3) Nishida,S.,Hattori,N.,Nakade,N.,Takigawa,H., Trans. JSME, Series A,Vol.64,No.621(1998), pp. 1215-1220.

(4) Nisitani,H.,Fukuda,T., Trans.JSME, Series A, Vol.59, No.558(1993), pp.311-318.

(5) Morimoto,A.,Matsumoto,E., Takeda,H., Trans. JSME, Series A, Vol.66, No.647(2000), pp.1337-1342.

(6) Masuda,C.,Nishijima,S.,Tanaka, Y., Trans. JSME, Series A, Vol.52, No.476(1986), pp.847-852.

(7) Majima,T.,Anzai,M.,Nakazawa,H., Trans. JSME, Series A, Vol.52, No.476 (1986), pp.1171-1176.

(8) Majima,T., Ogata, Y.,Nakazawa,H., Trans. JSME, Series A, Vol.53, No.488(1987), pp. 809-815.

(9) Geni,M.,Yanagi,K.,Kikuchi,M., Trans. JSME, Series A, Vol.66, No.648(2000), pp.1461-1467.

(10) Otsuka,A.,Miyata, T.,Nishimura,S.,Kimura,M., Mabuchi,M., Journal of the Society of Materials Science, Japan, Vol.29, No.322(1980), pp.717-723.

(11) Mutoh,Y.,Sakamoto,I.,Nomura,K.,Aya,K., Trans. JSME, Series A,Vol.51, No.468(1985), pp.2008-2013.

(12) Majima,T., Miyagawa,M., Journal of the Society of Materials Science, Japan, Vol.29, No.317(1980), pp.130136.

(13) Majima, T., Trans. JSME, Series A, Vol.57, No.534(1991), pp.398-403.

(14) Masuda,M.,Tozawa, Y., Trans. JSME, Vol.27, No.178 (1961), pp.776-782.

(15) Fujisaki,W.,Nisitani,H.,Tanaka,S., Teranishi, T., Trans. JSME, Series A,Vol.60, No.575(1994), pp.1545-1550.

(16) Nisitani,H.,Fujisaki,W., Trans. JSME, Series A, Vol.60, No.579(1994), pp.2525-2531.

(17) Takase,T.,Koyama,A.,Yoneda, R, Journal of the Society of Materials Science,Japan, Vol.56, No.12(2007), pp.11451149.

(18) Kishimoto,K.,Takeuchi,N.,Aoki,S., Trans. JSME, Series A, Vol.57, No.539(1991), pp.1506-1513.

(19) McMeeking, R. M., J. Mech. Phys. Solids, Vol.25(1977), pp.357-381.

(20) Rice, J. R, Rosengren, G. F., J. Mech. Phys. Solids, Vol.16 (1968), pp.1-12.

(21) Gotoh,M.,Amaki,H.,Tanaka,K., Trans. JSME, Series A, Vol.53, No.491(1987), pp.1440-1446.

(22) Aoki,S.,Amaya,K.,Suga,K.,Sekido,K., Trans. JSME, Series A, Vol.67, No.664(2001), pp.1892-1897.

(23) Shiraki,N.,Nakayama,S.,Sugiyama,Y., Asami,K., Trans. JSME, Series A,Vol.63, No.611(1997), pp.1437-1441. 